tinually re-examining some of their systems and stressing the need for yet another consideration of the relations between science and philosophy. Phenomenology has not escaped, but hàs been provisionally eased out a little on a frame of neopositivism. But the source of inspiration is still Husserl himself. Even his omissions and denials possess importance. For example, for him experience is immediately social in a limited sense, but to say "that one's own experience contains the actual experience of others as real, immanent elements" would be inacceptable by him.

Already in this review a mild defence of introspective methods in experimental psychology has been offered. In virtue of certain materialistic approaches to phenomenology which have keen made, it is unavoidable that they must kecome attractive targets. But their very weakness was one reason among several which impelled the then youthful Wertheimer to heroic efforts to end or to mend psychology as it then was. The result was the founding of the Gestalt concept. Ironical as it may be, perhaps intentional-history is asserting itself within the sphere of embryonic research.

That phenomenology is an art, a methodology and even a way of life all at once, should not blind us to its main characteristic as a mental construct suitable for dealing with the Universal rather than with the Particular. It is therefore not surprising that some of Husserl's followers should ke attempting something like a metaphysics of the factual element. One such system is sketcked in the work now before us. It is distinguished for its moderation and resilience. At least, it is held, mankind can express a desire to understand the world without postulating that it is wholly 'intelligible'. It will suffice for the purpose if the world is 'fact', but not 'mere fact'. The significant point is contained in the attitude that slavery to fact may ke quite as oppressive as that to 'authority" and the rationalizers. The latter types of bondage produced a series of explosions too well known to need recapitulation here. But a decision in advance never to venture outside 'mere fact' (if only, so to say, for fun, to see what happens) is as dyspeptic as it is unenterprising. Metaphysics is not prepared to come to terms finally either with 'authority' or with 'mere fact', if only because, should the world be meaningless, so would metaphysics be too. Doubtless there will be some dissent from much of this, but it is refreshingly robust all the same. One should not read these essays in and around Husserl's life and influence unless reasonably shock-proof. Their charm -which applies to one and all-resides very largely in an engaging humility and a certain lack of the doctrinaire, ready to 'take it all back' if something better can te found.

A contribution entitled "Men and the Law" is included in the collection. At first glance it would seem to have little to do with phenomenology. But it is followed by another, the theme of which is symbolic logic. The juxtaposition of these two articles was a happy thought, for between them they supply something very valuable indeed. Briefly, it amounts to this. The law says yes or no. It is not directly concerned with the vast majority of the events of daily life, which fall well within the excluded middle. Its power is of another kind. Now mathematicians are intent upon the quest of finding a place for possibility in symbolic logic, as 'objectivized' by Hilbert's quantifier $(\exists x)$. Is it at least conceivable that, far ahead, some light will come from this quarter to -illuminate the very practical twilight subjects like rheology and, more generally, the applied sciences? A philosophy of the latter is awaited with some impatience for regjons in which academic simplifications do not, and cannot, hold, and wherein 'facing the facts' is almost literally all that can be done.

So now, Prof. Marvin Farber and his colleagues bring their tribute volume to an end. Poured forth in honour of a master mind, their libations leave a most gracious and lasting impress, as they trickle silently away.

\section{ESTABLISHMENT OF VEGETATION ON COAL TIPS AND OTHER SPOIL MOUNDS}

\author{
By J. W. B. SISAM \\ Imperial Forestry Bureau, Oxford \\ AND \\ DR. R. O. WHYTE \\ Imperial Bureau of Pastures and Forage Crops, \\ Aberystwyth
}

CPOIL mounds of varying type and composition $S$ are the inevitable end-product of many mining and manufacturing operations. Anyone familiar with the Black Country of England or the mining areas of South Wales, to cite two important examples, well knows how the countryside can be disfigured by these tips. Under natural conditions considerable time may elapse before even a coarse grass or scrub vegetation becomes established on such material, and then the result is of little asthetic or economic value. While in the past a certain amount of work has been undertaken locally in reclaiming tips of various kinds, usually through afforestation, such programmes have been limited in scope and dificult to maintain. It is only recently that there has been any widespread interest regarding the vegetation of spoil mounds by artificial means, with or without preliminary levelling, in order to improve the landscape, amenities and living conditions in the districts concerned. It is the purpose of this short article to indicate how know. ledge on the ecology of pioneer vegetation, both forest and grassland, can be applied to this particular problem, and to suggest methods of establishing a vegetation cover on what may appear to be a not particularly promising medium.

In Great Britain, the industries responsible for spoil mounds include coal-mining, quarrying for iror and other minerals, and the manufacture of chemicals pottery and glass. The vegetation of the tips anc general waste material from these industries has beer referred to in the reports of the Scott and Kenne: Committees, and is receiving the attention of severa Ministries, of local planning organizations such as the West Midland Group on Post-War Reconstructior and Planning, of local authorities such as borougl councils in South Wales, and of the industries them selves. The problem is also being studied in th. United States, South Africa and Germany.

When once the planning authority has decided of the general purpose of the reclamation, whether fo amenity purposes (landscape improvement and pro vision of parks and recreation grounds) or for yieldin an economic return, it becomes the task of the plan ecologist and the soil specialist to decide which specie 
of trees, shrubs, herbage or other plants are adapted to this rather abnormal environment, and what method of establishment would be most eificient for the purpose in view. Surveys are necessary to determine the degree of weathering of spoil material, the nutrient or toxic status of the forming soil, the soil moisture and degree of drainage within tips, the surface temperature and the degree of erosion and soil-wash. The problem of air impurities in districts still in active production must also be considered.

It is probably correct to say that the establishment of grass swards should be attempted only when levelling 'can be done. If the cost of such an operation with modern mechanical equipment is not prohibitive, and land adjacent to the tip is available, the ultimate creation of pastures or parkland can be visualized. The establishment of grass can be greatly accelerated if a covering of six to nine inches of soil or a compost made from town waste can be provided, but it should be possible to establish certain types of grass even on the crude tip material after a certain amount of weathering has taken place, especially if the weathered surface layer on the tops of the mounds is carefully preserved during levelling.

If soil is available, the usual technique of establishing grass on poor soils can be adopted, starting possibly with rape and turnips that can be grazed with sheep, and following with a grass-legume seeds mixture composed according to local conditions and requirements. Direct turfing is also possible, particularly in the formation of bowling greens.

If soil is not available, it will probably be necessary to use species with very low fertility requirements, not generally used for agricultural purposes. Surveys of natural revegetation made by botany students will provide useful information for this work. There are indications that grasses requiring low fertility such as Aira ccespitosa, certain species of Agrostis, and certain weeds could be established, and it may become necessary to commence the production of seed. of unusual plants for this purpose. Lupins are important legumes that can be grown for increasing the nitrogen content of the soil. The non-palatable species are generally used, but it is desirable to test the sweet varieties, as these could be grazed at the appropriate time, and the soil would thus gain considerably from the sheep droppings. Unorthodox methods such as the spreading of mixtures of root or rhizome cuttings of bracken or Agrostis may be applicable in certain circumstances. The ultimate aim of all this work must be to improve the organic matter content and nutrient status of the soil as rapidly as possible, up to a stage when the establishment of secondary and superior species with higher fertility requirements can be attempted.

The creation of market gardens and allotments on tip soil is dependent upon the availability of organic manures. If stable manure or similar material can be obtained, good crops of vegetables can be expected, and have actually been obtained on the tops of coal tips.

In many cases, however, tree planting will be the method adopted for spoil-mound reclamation; the cost of levelling may be prohibitive, or the general landscape plan may require the establishment of plantations for timber production or the planting of individual trees in parkland development on levelled or partly levelled tips. Here the general principles of the ecology of pioneer vegetation will again apply, although this aspect of the subject raises a number of special problems.
The choice of tree species, the size and quality of the planting stock, and the method of planting to be used can be decided only after a careful study of the site. Waste materials are extremely variable in composition and rate of weathering, and species that do well on one.site may not do so on apparently similar sites; each case must be dealt with on its own merits. Mention has already been made of the site factors that require to be surveyed; where possible a chemical analysis should be made of the constituent material of the tip before any reclamation work is undertaken.

Old, well-weathered spoil mounds, particularly those consisting of easily decomposed materials such as certain shales and fire clay that has been burnt, are readily covered with natural vegetation and should offer little difficulty in the establishment of trees. On the poorer sites, where the material is largely unweathered and sterile, it is of the greatest importance to improve the humus content and moistureretaining capacity of the soil as rapidly as possible. The first trees to be planted on these sites should have the characteristics of true pioneer species-low nutrient requirements, a vigorous and penetrating root-growth, and the ability to build up the organic content of the surface soil through the annual fall of leaves and other debris. Species of willow, birch, poplar and alder are useful for this purpose.

Best results may be obtained if the trees are planted with their roots in a ball of earth, and such treatment is essential if species with more exacting site requirements are used. In general, it is recommended that the planting stock be 1-year transplants not more than $2 \mathrm{ft}$. in height, although poplars may be up to $5 \mathrm{ft}$. high; the plants used should have a well-developed fibrous root system and should be planted to the same depth as when taken from the nursery. They should be spaced at about 5 -ft. intervals and left to form canopy before thinning. Poplars have been successfully established on a fairly well weathered tip of shale and clay by placing euttings in holes 12 in. deep, made with a crowbar, and consolidating colliery slag around the cuttings. The only subsequent treatment was the application of manure to the base of the saplings at the end of the first year.

If feasible, a new tip may usefully be covered with a layer of soil, and the use of 'over burden' from sand quarries has been suggested for this purpose. The danger of drought in the summer, due to lack of contact with sub-soil moisture, can be counteracted by placing some peat in the planting hole. Alternatively, if the tip has weathered for some time and bears a skin of coarse grass over unweathered material, the turf removed for purposes of tree-planting should be inverted, placed in the planting hole and covered with fresh soil. Moisture conditions will be improved as the turf gradually rots and forms a humus layer. In addition, the sowing of common lupin seed in the inverted turf some time before the trees are planted will help to increase the available nitrogen in the soil. Gorse, broom and alder are also valuable as nitrogen fixers, and, in addition, provide shelter on bare, exposed sites if established before the young plants of the main crop are put in. As site conditions improve, species of greater economic value, having higher fertility requirements, may be used. Among the tree species that have been recommended for use on spoil mounds in Great Britain, in addition to those already noted, are mountain ash, elder, wild cherry, wych elm, hawthorn, laburnum, sycamore, ash, Austrian pine, Corsican pine, Scots 
pine and European larch. Of the conifers, Corsican pine is particularly recommended, as it is not exacting in its requirements, stands up to smoky conditions, and thrives on a low rainfall.

Apart from soil conditions, the choice of tree species may be limited owing to exposure of the site to wind and insolation, especially at high elevations. In exposed situations, where shelter is required at any cost, alder, wych elm, thorn, elder, willow and stout birch plants have been recommended. The conifers, Sitka spruce and Scots pine, are suited to planting at relatively high altitudes. On exposed sites it is important that the planting stock be not too large in order to avoid damage by wind before it becomes properiy acclimatized.

Air pollution by certain gases may prevent the establishment of any kind of vegetation, while with other forms of pollution, such as smoke, vegetation can be grown, but the species must be carefully selected. Deciduous species have an advantage over conifers in that they lose their foliage annually, whereas conifers usually retain their needles for several years. Among the species that have been recommended to stand up to smoky conditions are alder, willow, birch, mountain ash, London plane, certain species of poplar and Corsican pine.

A hazard to the success of spoil mound plantations that has nothing to do with choice of species or method of planting is the possible interference with, and injury and ultimate destruction of, the trees by animals or human beings. Fencing affords protection, but is expensive and not necessarily effective where children are concerned. It is far better to give them a personal constructive interest in the plantation by enlisting their help in its establishment.

The ultimate value of tree plantations depends not only on the successful establishment of the plants but also on their subsequent care, particularly in the early stages of development. Close attention should also be given to the sequence of succession that will best meet the needs of the planning authorities and at the same time satisfy ecological requirements.

With reference to the problem of spoil-mound reclamation in Great Britain, the general conclusion that can be drawn after visiting representative areas in the Birmingham conurbation and in South Wales is that a great deal can be done in a short period, and reasonably soon after tipping has stopped, provided soil analyses are made and expert advice taken regarding the selection of species and the methods that are to be adopted. A full statement of the information available from the literature and from local experience is now in preparation, to be issued as a Joint Publication of the Imperial Agricultural Bureaux.

\section{OBITUARIES}

\section{Sir Julien Cahn, Bart.}

Sir Julien Cahn, Bart., who died on September 26, aged sixty-two, was known to a wide circle as a keen sportsman; he was particularly interested in cricket and he took teams to many parts of the Empire and to many countries. He was a far-seeing philanthropist, being a generous supporter of medicine and hospitals and particularly of the cause of reducing maternal mortality. It was due, too, to Sir Julien Cahn's munificence that it was possible to found the Cahn Hill Improvement Scheme in connexion with the University of Wales, Aberystwyth-that was in 1932 and before any purposeful action was being taken to increase home food production in the event of war. The nation owes much to Sir Julien Cahn because, as a result of the experiments then started on the hill and rough lands of Wales, the foundations were laid for establishing a technique applicable to the radical improvement and more intensive utilization not only of such lands but also of much neglected pasture in the lowlands.

During the War of 1914-18, the rough and hill lands of England and Wales (more than 5,000,000 acres) made no materially increased contribution to our food resources : in this War the matter has been very different, as is well exemplified by the pioneer endeavours of the Montgomeryshire War Agricultural Committee and by the work undertaken by the Committees in Lancashire and Breconshire and by those of many other counties of England and Wales. The success and magnitude of all this work have been, in no small measure, due to the good and quick start that was rendered possible by the results of the investigations which Sir Julien Cahn had so largely financed. Of the many lessons of the War, few are more compelling than the emphasis that must necessarily be put on the importance of the rising generation and on a thriving agriculture, capable at all times of producing an abundance of food.

The War has, therefore, greatly accentuated the wisdom behind, and the value to the nation of, Sir Julien Cahn's benefactions--benefactions which have served as an inspiration to large numbers of workers in two of the most important fields of national endeavour.

R. G. Stapledon.

\section{Prof. F. Plzák}

News has reached London that the death of Dr. F. Plzák, professor of organic chemistry at the Charles University of Prague, occurred there on May 4. Prof. Plzák, who was sixty-six years of age, had occupied the chair of organic chemistry since 1910 and was at one time well known in America and to a less extent in Great Britain, being a frequent visitor prior to the outbreak of the War of 1914-18. Before entering the University he was employed in a pharmacy and did not graduate until he was twenty. five years old. Then he went to Zurich to study under Prof. Lorenz before becoming, first lecturer and then (1910) professor of organic chemistry. His researches were not numerous and mainly related to the lesser known alkaloids (for example, tubocurare) and glycosides (for example, cyclamin, $\mathrm{C}_{63} \mathrm{H}_{110} \mathrm{O}_{32}$, which he found in potatoes as well as in cyclamen tubers, and showed to contain various sugar groups). Plzák was part-author (with Prof. Baborovský) of a standard Czech work on electrochemistry.

As a part of the Czech University, his laboratory was closed by the Germans in 1939 and Plzák, like the other professors, was relieved of his post. After. wards the Chemical Institute was reopened with a German staff.

WE regret to announce the following deaths :

Dr. E. L. G. Clegg, director of the Geological Survey of India, on September 8.

The Right Hon. Sir William Mulock, K.C.M.G., vice-chancellor (1881-1900) and chancellor since 1924 of the University of Toronto, on October 1, aged one hundred. 